\title{
Composition, Mineral and Fatty Acid Profiles of Milk from Goats Fed with Different Proportions of Broccoli and Artichoke Plant By-Products
}

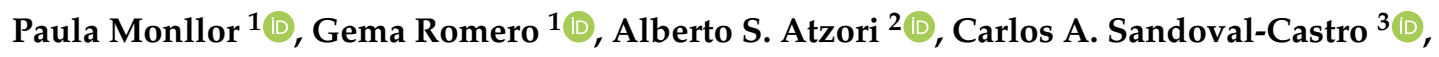 \\ Armín J. Ayala-Burgos ${ }^{3}$, Amparo Roca ${ }^{1}$, Esther Sendra ${ }^{1}$ (D) and José Ramón Díaz ${ }^{1, *}$ \\ 1 Departamento de Tecnología Agroalimentaria, Universidad Miguel Hernández de Elche, \\ 03312 Alicante, Spain; pmonllor@umh.es (P.M.); gemaromero@umh.es (G.R.); aroca@umh.es (A.R.); \\ esther.sendra@umh.es (E.S.) \\ 2 Dipartimento di Agraria, Università degli Studi di Sassari, 07100 Sassari, Italy; asatzori@uniss.it \\ 3 Facultad de Medicina Veterinaria y Zootecnia, Universidad Autónoma de Yucatán, Mérida 97100, Mexico; \\ carlos.sandoval@correo.uady.mx (C.A.S.-C.); aayala@correo.uady.mx (A.J.A.-B.) \\ * Correspondence: jr.diaz@umh.es; Tel.: +34-966-749-707
}

Received: 28 April 2020; Accepted: 28 May 2020; Published: 1 June 2020

\begin{abstract}
In the Mediterranean region, artichoke and broccoli are major crops with a high amount of by-products that can be used as alternative feedstuffs for ruminants, lowering feed costs and enhancing milk sustainability while reducing the environmental impact of dairy production. However, nutritional quality of milk needs to be assured under these production conditions and an optimal inclusion ratio of silages should be determined. This work aimed to evaluate the effect of three inclusion levels $(25 \%, 40 \%$, and $60 \%$ ) of these silages (artichoke plant, AP, and broccoli by-product, $\mathrm{BB}$ ) in goat diets on milk yield, composition, and mineral and fatty profiles. Treatments with $60 \%$ inclusion of AP and BB presented the lowest milk yield. No differences were found on the milk mineral profile. Inclusion of AP in the animals' diet improved the milk lipid profile from the point of view of human health (AI, TI) compared to BB due to a lower saturated fatty acid content (C12:0, C14:0, and C16:0) and a higher concentration of polyunsaturated fatty acids (PUFA), especially vaccenic acid (C18:1 trans11) and rumenic acid (CLA cis9, trans11), without any differences with the control treatment.
\end{abstract}

Keywords: fatty acid profile; mineral profile; CLA; milk yield; circular economy

\section{Introduction}

Regarding milk consumption worldwide, cow's milk occupies first place, followed by buffalo and thirdly, that of goat [1], which continues to increase [2] due to its high level of calcium, phosphorus, and animal protein. In addition, goat milk has been classified as a substitute for cow's milk in those people who suffer from some type of allergy to this food [3]. Goat's milk is a source of nutrients in the human diet due to its content of Se and polyunsaturated fatty acids (PUFA), such as vaccenic and rumenic acid or CLA $[4,5]$, which can influence the prevention of certain types of cancers and cardiovascular diseases [6,7]. The literature contains many studies of how diet affects the performance and quality of ruminant milk. Hilali et al. [8] and Cappucci et al. [9] found that the inclusion of agro-industrial and olive by-products in ewes' diets enhanced milk fatty acid profile, with no effects on performance and milk macro-composition. On the other hand, Schulz et al. [10] observed changes in milk fatty acid profile in cows fed with red clover silage in comparison with maize silage. Finally, Monllor et al. [11] showed slight differences in fat and protein levels of milk from goats fed with artichoke by-products and an increase of Selenium and polyunsaturared fatty acid contents. 
The inclusion of agricultural by-products in ruminant diets does not have to affect the sensory quality of dairy products. Such is the case in Caputo et al. Ref. [12], who did not observe differences in the aromatic profile of milk and dairy products from cows fed with destoned olive cake.

It is necessary to enhance the sustainability of milk production and reduce the impact of animal feeding. The use of local resources, especially if recovered from by-products, may significantly enhance milk sustainability. Artichoke (Cynara scolymus L.) and broccoli (Brassica oleracea var. Italica) crops generate large quantities of by-products. According to Food and Agriculture Organization of the United Nations (FAO) [13], 1,505,328 $t$ of artichoke and 25,984,758 $t$ of broccoli were harvested worldwide in 2017. The artichoke plant is a waste, mainly formed of stems and leaves, and some unharvested inflorescences are left in the field after harvest of inflorescences for human consumption. This by-product has traditionally been used by grazing small ruminants or collected and brought to dairy farms [14]. The yield of green fodder in this crop is $11.1 \mathrm{t} /$ ha [15], which, taking into account FAO's cultivated area data [13] (2017) worldwide (122,390 ha), would result in an annual production of more than 1,300,000 $\mathrm{t}$ of available artichoke plant. According to Ros et al. [16], 29.5\% of harvested broccoli is composed of stems and inflorescences that are not suitable for human consumption. Broccoli by-product is considered, from the point of view of animal feed, more as a concentrate than as a forage, due to its low fibre content and high protein level [17].

Agri-food by-products, whether coming from stubbles left in the field or the canning industry, constitute a supply of alternative forage for livestock, allowing the use of local resources and reducing feed costs without damaging animal performance and productivity, as long as the rations that include these feeds are balanced. The use of these by-products can also be a solution to minimise residues produced by the agro-food industry and thus reduce removal costs and emissions of polluting gases caused by uncontrolled fermentation of these agricultural wastes. In addition, the use of agro-food by-products reduces the land and supplies dedicated to the development of livestock feed, thus aiding the circular economy. However, the strong seasonality and high water content of these feeds limits their systematic use in animal feeding. Through lactic fermentation, the silage is able to conserve perishable products so that cellular respiration is suppressed, protein and vitamin degradation is prevented, and clostridial fermentation is avoided [18], reaching levels of safety that do not endanger the health of animals and do not compromise the hygienic-sanitary quality of milk or derived products.

Previous studies have shown that these by-product silages have the proper fermentative and nutritional conditions to become part of sheep and goat diets $[14,19,20]$. The references found in the literature about the effect of consuming these silage by-products on milk quality and composition, as well as on the health status of animals, are scarce [21-23]. None of these studies have been conducted in dairy goats, except Muelas et al. and Monllor et al. [11,24], where the effect of up to $25 \%$ inclusion of silage artichoke plant on the technological aptitude of milk was studied.

With the previous background, it is hypothesised that these by-products may be incorporated into the diet of lactating goats without detriment to their milk yield and quality. Therefore, the objective of this experiment is to study the effect of the inclusion of by-product silages (artichoke plant and broccoli by-product) in the ration of goats on milk production, macro-composition, and quality and determine the optimum level of inclusion in the ration among the three levels tested $(25 \%, 40 \%$, and $60 \%$ ), with the aim of assuring milk nutritional quality within an integrative approach of enhanced sustainability of milk production.

\section{Materials and Methods}

\subsection{Animals and Facilities}

The animals used in this experiment were Murciano-Granadina lactating goats housed in the experimental and teaching farm of the Miguel Hernández University, Spain, with access to outdoor yards $\left(2.30 \mathrm{~m}^{2} / \mathrm{animal}\right)$, free access to water, and enough feeding space for all animals (at least $35 \mathrm{~cm} /$ animal and $1.50 \mathrm{~m}^{2} /$ animal as total indoor space) with a straw bed. As usual in the region, 
the animals were milked once a day (Casse milking parlour, $2 \times 12 \times 12$, GEA, Germany) and fed twice a day, at 8:00 a.m. and 2:00 p.m. This study was approved by the Ethical Committee of Experimentation of the Miguel Hernández University (code UMH.DTA.GRM.01.15).

\subsection{Experimental Design}

On the fourth month of lactation, 63 lactating goats were selected $(41.2 \pm 7.15 \mathrm{~kg}, 2.25 \pm 0.80 \mathrm{~kg} / \mathrm{day}$, $5.39 \pm 0.48 \mathrm{Log}$ cell $/ \mathrm{mL}$ ). The animals were divided into seven homogeneous groups regarding body weight (BW), daily milk yield, and somatic cell count (SCC).

A short-term experiment was conducted to study the effect of inclusion in the diet of two by-product silages (artichoke plant, AP, and broccoli by-product, BB), of which their composition and fermentation quality are shown in Table 1 . They were included at three levels each $(25 \%, 40 \%$, and $60 \%$, expressed on a dry matter basis of the total ration); thus, seven rations were tested: $25 \%, 40 \%$, and $60 \%$ of artichoke plant silage (AP25, AP40, and PAP60, respectively), the same percentages of broccoli by-product silage (BB25, BB40 and BB60), and a control diet (C), which represents the conventional ration used to feed dairy goats (alfalfa hay and a mixture of grains). Diets were formulated according to the recommendations of Fernandez et al. Ref. [25], an average amount of $2.23 \mathrm{~kg}$ DM/day was offered, and the seven rations were isoenergetic and isoproteic. Table 2 shows the ingredient proportion and the chemical composition of each diet. Once the pre-experimental sampling was performed, the experiment lasted 4 weeks. In the first two weeks, each group of animals adapted to their diet. In the next two weeks, data on feed consumption, milk yield, and body weight were recorded and blood and milk samples from animals were collected weekly for subsequent laboratory analyses. Bulk milk samples were collected weekly and used to determine mineral and fatty acid profile concentrations.

Table 1. Chemical composition $(\mathrm{g} / \mathrm{kg} \mathrm{DM})$ and fermentation quality $(\mathrm{g} / \mathrm{kg} \mathrm{DM})$ of silages included in experimental diets.

\begin{tabular}{ccc}
\hline Item & BB & AP \\
\hline & Chemical Composition & \\
\hline $\mathrm{DM}(\mathrm{g} / \mathrm{kg}$ of FM, as fed $)$ & 154 & 258 \\
OM & 821 & 828 \\
CP & 174 & 78.1 \\
CF & 214 & 296 \\
NDF & 430 & 571 \\
ADF & 326 & 374 \\
ADL & 63.4 & 108 \\
EE & 32.1 & 34.6 \\
TP & 6.73 & 4.96 \\
\hline VFA and Fermentative Metabolites & \\
\hline Lactate & 30.8 & 17.0 \\
Acetate & 117 & 35.2 \\
Propionate & 14.6 & $n . d$. \\
Butyrate & 3.80 & 8.56 \\
Ethanol & 14.6 & 3.25 \\
Ammonia N & 1.65 & 0.149
\end{tabular}

BB: Broccoli by-product silage; AP: Artichoke plant silage; DM: Dry matter; FM: Fresh matter; OM: Organic matter; CP: Crude protein; CF: Crude fibre; NDF: Neutral detergent fibre; ADF: Acid detergent fibre; ADL: Acid detergent lignin; EE: Ether extract; TP: Total polyphenols; VFA: Volatile fatty acids; n.d.: Not detected. 
Table 2. Ingredients of experimental diets and their nutritional value.

\begin{tabular}{|c|c|c|c|c|c|c|c|}
\hline \multirow{2}{*}{ Item } & \multicolumn{7}{|c|}{ Diets } \\
\hline & $\mathrm{C}$ & AP25 & AP40 & AP60 & BB25 & BB40 & BB60 \\
\hline \multicolumn{8}{|c|}{ Ingredients (g/100 g DM) } \\
\hline Alfalfa hay & 38.0 & 14.7 & - & - & 13.5 & 8.50 & 4.60 \\
\hline Oat & 16.0 & 15.0 & 13.0 & 8.0 & 35.0 & 26.5 & 26.6 \\
\hline Barley & 9.50 & 9.00 & 8.00 & 4.51 & 5.50 & 3.72 & 1.23 \\
\hline Corn & 9.08 & 8.43 & 8.00 & 4.35 & 5.16 & 3.60 & 1.19 \\
\hline Dried sugar beet pulp & 7.36 & 7.00 & 6.50 & 3.53 & 4.18 & 3.00 & 0.960 \\
\hline Sunflower meal & 3.36 & 3.12 & 3.00 & 1.61 & 2.00 & 1.33 & 0.440 \\
\hline Peas & 2.50 & 2.32 & 2.09 & 1.20 & 1.42 & 0.990 & 0.330 \\
\hline Cottonseed & 2.50 & 2.32 & 2.09 & 1.20 & 1.42 & 0.990 & 0.330 \\
\hline Soybean meal 44\% & 4.00 & 6.00 & 10.0 & 12.0 & 2.00 & 2.00 & 1.00 \\
\hline Corn DDGS & 3.00 & 3.00 & 2.50 & 1.38 & 2.00 & 1.14 & 0.380 \\
\hline Sunflower seeds & 2.00 & 1.74 & 2.40 & 1.00 & 1.07 & 0.740 & 0.250 \\
\hline Beans & 1.25 & 1.16 & 1.05 & 0.600 & 1.00 & 0.500 & 0.160 \\
\hline Wheat & 1.00 & 0.770 & 1.00 & 0.400 & 0.470 & 0.330 & 0.110 \\
\hline Soy hulls & 0.420 & 0.390 & 0.350 & 0.200 & 0.240 & 0.160 & 0.050 \\
\hline Silage & - & 25.0 & 40.0 & 60.0 & 25.0 & 40.0 & 60.0 \\
\hline kg DM offered/day/animal & 2.24 & 2.26 & 2.20 & 2.30 & 2.22 & 2.21 & 2.20 \\
\hline \multicolumn{8}{|c|}{ Chemical Composition } \\
\hline \multicolumn{8}{|c|}{$\mathrm{g} / \mathrm{kg} \mathrm{DM}$} \\
\hline $\mathrm{OM}$ & 935 & 915 & 901 & 884 & 916 & 904 & 885 \\
\hline $\mathrm{CP}$ & 162 & 160 & 163 & 157 & 162 & 165 & 169 \\
\hline $\mathrm{CF}$ & 195 & 202 & 196 & 237 & 180 & 180 & 183 \\
\hline NDF & 376 & 391 & 382 & 432 & 359 & 355 & 353 \\
\hline $\mathrm{ADF}$ & 243 & 248 & 239 & 281 & 225 & 226 & 231 \\
\hline ADL & 56.5 & 55.1 & 49.5 & 55.2 & 48.0 & 47.0 & 46.7 \\
\hline $\mathrm{EE}$ & 41.9 & 36.5 & 35.1 & 30.5 & 41.3 & 38.5 & 34.7 \\
\hline $\mathrm{TP}$ & 3.87 & 4.18 & 5.42 & 5.34 & 4.60 & 5.42 & 6.68 \\
\hline IVDMD & 715 & 715 & 710 & 665 & 780 & 747 & 757 \\
\hline${ }^{1} \mathrm{ME}(\mathrm{Mcal} / \mathrm{kg} \mathrm{DM})$ & 2.37 & 2.30 & 2.29 & 2.19 & 2.39 & 2.36 & 2.29 \\
\hline \multicolumn{8}{|c|}{ VFA and Fermentative Metabolites (g/kg DM) } \\
\hline Lactate & n.d. & 14.2 & 23.2 & 24.5 & 33.1 & 41.2 & 56.0 \\
\hline Acetate & n.d. & 4.91 & 6.04 & 11.9 & 15.1 & 11.0 & 37.8 \\
\hline Propionate & n.d. & n.d. & n.d. & n.d. & 2.63 & n.d. & 4.79 \\
\hline Butyrate & n.d. & n.d. & n.d. & n.d. & n.d. & n.d. & n.d. \\
\hline Ethanol & n.d. & 1.50 & 1.80 & 1.69 & 9.64 & 12.5 & 23.2 \\
\hline Ammonia $\mathrm{N}$ & 0.166 & 0.628 & 0.741 & 1.01 & 3.99 & 4.26 & 7.73 \\
\hline \multicolumn{8}{|c|}{ Fatty Acids Profile (g/100 g Total Fatty Acids) } \\
\hline C6:0 & 0.061 & 0.109 & 0.485 & 0.352 & 0.059 & 0.025 & 0.498 \\
\hline C12:0 & 0.183 & 0.286 & 0.151 & 0.050 & 0.242 & 0.328 & 0.146 \\
\hline C14:0 & 0.440 & 0.502 & 0.413 & 0.357 & 0.542 & 0.539 & 0.465 \\
\hline C16:0 & 17.2 & 18.1 & 18.3 & 17.3 & 19.8 & 17.7 & 21.2 \\
\hline C16:1 c9 & 0.300 & 0.348 & 0.369 & 0.364 & 0.374 & 0.312 & 0.592 \\
\hline C18:0 & 3.25 & 3.08 & 2.93 & 3.63 & 2.96 & 3.34 & 2.76 \\
\hline C18:1 c9 & 26.4 & 25.1 & 22.8 & 31.3 & 30.1 & 34.3 & 21.9 \\
\hline C18:1 c11 & 1.06 & 1.11 & 1.33 & 1.12 & 2.00 & 2.23 & 3.74 \\
\hline C18:2n6 & 44.0 & 42.0 & 40.5 & 32.3 & 35.5 & 29.4 & 29.4 \\
\hline C18:3n3 & 4.07 & 4.79 & 6.75 & 6.43 & 5.79 & 8.18 & 13.0 \\
\hline C20:0 & 0.463 & 0.757 & 0.884 & 1.19 & 0.493 & 0.679 & 0.838 \\
\hline C20:1n9 & 0.323 & 0.408 & 0.300 & 0.336 & 0.464 & 0.386 & 0.423 \\
\hline C22:0 & 0.457 & 0.546 & 0.519 & 0.960 & 0.393 & 0.784 & 0.640 \\
\hline C24:0 & 0.336 & 0.493 & 0.392 & 0.411 & 0.365 & 0.600 & 0.652 \\
\hline SFA & 23.3 & 24.7 & 26.4 & 26.8 & 25.5 & 24.6 & 29.5 \\
\hline
\end{tabular}


Table 2. Cont.

\begin{tabular}{|c|c|c|c|c|c|c|c|}
\hline \multirow{2}{*}{ Item } & \multicolumn{7}{|c|}{ Diets } \\
\hline & $\mathrm{C}$ & AP25 & AP40 & AP60 & BB25 & BB40 & BB60 \\
\hline MUFA & 28.2 & 27.6 & 26.1 & 33.7 & 33.0 & 37.5 & 27.5 \\
\hline PUFA & 48.7 & 48.3 & 47.7 & 40.0 & 41.5 & 38.1 & 43.2 \\
\hline \multicolumn{8}{|c|}{ Mineral Profile } \\
\hline $\mathrm{Na}(\mathrm{g} / \mathrm{kg} \mathrm{DM})$ & 2.89 & 5.83 & 7.34 & 12.1 & 2.37 & 5.28 & 5.09 \\
\hline $\mathrm{Mg}(\mathrm{g} / \mathrm{kg} \mathrm{DM})$ & 2.66 & 3.24 & 3.05 & 3.63 & 2.06 & 2.52 & 2.43 \\
\hline K (g/kg DM) & 13.5 & 14.3 & 14.1 & 17.8 & 17.8 & 19.4 & 30.1 \\
\hline $\mathrm{Ca}(\mathrm{g} / \mathrm{kg} \mathrm{DM})$ & 5.90 & 10.8 & 11.2 & 17.0 & 5.62 & 8.91 & 7.49 \\
\hline P (g/kg DM) & 2.76 & 4.09 & 3.69 & 3.56 & 3.40 & 3.61 & 4.18 \\
\hline $\mathrm{S}(\mathrm{g} / \mathrm{kg} \mathrm{DM})$ & 2.89 & 3.45 & 3.06 & 3.78 & 3.40 & 4.27 & 6.58 \\
\hline Se (mg/kg DM) & 0.198 & 0.190 & 0.150 & 0.243 & 0.183 & 0.135 & 0.167 \\
\hline $\mathrm{Zn}(\mathrm{mg} / \mathrm{kg} \mathrm{DM})$ & 49.4 & 44.2 & 41.3 & 34.1 & 43.6 & 42.5 & 36.9 \\
\hline $\mathrm{Cu}(\mathrm{mg} / \mathrm{kg} \mathrm{DM})$ & 6.15 & 6.42 & 5.83 & 6.76 & 5.68 & 4.67 & 5.41 \\
\hline $\mathrm{Fe}(\mathrm{mg} / \mathrm{kg} \mathrm{DM})$ & 129 & 414 & 287 & 460 & 175 & 161 & 235 \\
\hline $\mathrm{Mn}(\mathrm{mg} / \mathrm{kg} \mathrm{DM})$ & 42.1 & 47.7 & 44.2 & 54.0 & 38.5 & 34.6 & 35.7 \\
\hline
\end{tabular}

C: Control diet; AP: Diet that includes artichoke plant silage; BB: Diet that includes broccoli by-product silage; DM: Dry matter; FM: Fresh matter; OM: Organic matter; CP: Crude protein; CF: Crude fibre; NDF: Neutral detergent fibre; ADF: Acid detergent fibre; ADL: Acid detergent lignin; EE: Ether extract; TP: Total polyphenols; IVDMD: In vitro dry matter digestibility; ME: Metabolisable energy; VFA: volatile fatty acids; SFA: Saturated fatty acids; MUFA: Monounsaturated fatty acids; PUFA: Polyunsaturated fatty acids, n.d.: Not detected ${ }^{1}$ [26].

\subsection{Analysed Variables}

The body weight of the animals (BW, $\mathrm{kg})$ was recorded by weighing them on a scale $( \pm 100 \mathrm{~g}$, APC, Baxtran, Vilamalla, Spain). The feed consumption was measured twice a week and calculated by the average of the difference of the feed offered and refused on dry matter basis. The chemical composition of the silages and diets was analysed as previously described by Monllor et al. [11]. Dry matter (DM, g/kg; method 930.5), organic matter (OM, g/kg DM; method 942.05), ether extract (EE, g/kg DM; method 920.39), crude protein (CP, g/kg DM; method 984.13), and crude fibre (CF; g/kg DM; method 962.09) were determined following AOAC [27] procedures. Neutral detergent fibre (NDF, g/kg $\mathrm{DM})$, acid detergent fibre (ADF, g/kg DM), and acid detergent lignin (ADL, g/kg DM) were analysed according to Van Soest et al. [28]. Total polyphenol content (TP, g/kg DM) was measured by the Folin-Ciocalteu method [29]. Volatile fatty acids (VFA, g/kg DM) (acetic, propionic, and butyric acid, also including lactic acid and ethanol) were determined by HPLC liquid chromatography (Agilent 1200, Santa Clara, CA, USA and Supelcogel C-610H column: $30 \mathrm{~cm} \times 7.8 \mathrm{~mm}$ ID, Saint Louis, MO, USA), by Feng-Xia et al. [30] methodology. Apparent in vitro dry matter digestibility (IVDMD, g/kg DM) was measured according to Menke and Steingass [31]. Fatty acid profile analysis in diets was performed by direct methylation on the lyophilised samples, without prior extraction of the fat, according to Kramer et al. [32] and were identified by a gas chromatograph (GC-17A Shimadzu, Kyoto, Japan) coupled with a flame ionisation detector (FID) equipped with a capillary column (CP Sil $88100 \mathrm{~m} \times$ $0.25 \mathrm{~mm}$ internal diameter and $0.20 \mu \mathrm{m}$ internal coverage, Agilent, Santa Clara, CA, USA). A mixture of fatty acid methylated esters (FAME;18912-1AMP, Sigma-Aldrich, Saint Louis, MO, USA) was used for identification of the fatty acids of the samples.

Dietary and milk minerals ( $\mathrm{Na}, \mathrm{Mg}, \mathrm{K}, \mathrm{Ca}, \mathrm{P}, \mathrm{S}, \mathrm{Se}, \mathrm{Zn}, \mathrm{Cu}, \mathrm{Fe}$, and $\mathrm{Mn}$ ) were determined by carrying out a previous digestion of the samples, according to González Arrojo et al. [6]. Microwave (MW) digestion unit Ethos Easy, Milestone (Milestone, Srl, Sorisole, Italy) equipped with a rotor for 10 TFM (chemically modified PTFE) vessels was used for sample mineralisation. The microwave program consisted of four phases (i) $5 \mathrm{~min}$ at $1000 \mathrm{~W}$ at temperatures from 100 to $60^{\circ} \mathrm{C}$; (ii) $10 \mathrm{~min}$ at $1000 \mathrm{~W}$ from 165 to $80^{\circ} \mathrm{C}$; (iii) $5 \mathrm{~min}$ at $1000 \mathrm{~W}$ from 180 to $120^{\circ} \mathrm{C}$; and, (iv) $5 \mathrm{~min}$ at $700 \mathrm{~W}$ from 180 to $120^{\circ} \mathrm{C}$. The ICP-MS (inductively coupled plasma mass spectrometry) instrument used in this study was an Agilent 7700× Octopole Reaction System (ORS) (Agilent Technologies, Tokyo, Japan). The ICP-MS operating conditions were optimised for the simultaneous determinations of all elements. ICP-MS 
standard solutions were prepared daily by appropriate dilution of stock standard $1000 \mathrm{mg} / \mathrm{L}$ for each element in $2 \% v / v$ Suprapur HNO3. An appropriate internal standard was also required for each analyte to correct physical and/or matrix interferences in ICP-MS.

The milk yield ( $\mathrm{kg} /$ day) of every goat was determined during milking using a Lactocorder ${ }^{\circledR}$ device (Lactocorder, Balgach, Switzerland). This device collected a representative sample of $100 \mathrm{~mL}$ of milk at every milking of each animal for subsequent analysis. The macro-composition of milk (fat, protein, true protein, casein, whey protein, lactose, total solids, TS; non-fat total solids, NFTS; useful dry matter content, UDM, and ash; \%) and urea content ( $\mathrm{mg} / \mathrm{L})$ was determined by medium infrared spectroscopy equipment (MilkoScan ${ }^{\mathrm{TM}}$ FT2, Foss, Hillerød, Denmark). The SCC $\left(10^{3} \mathrm{cell} / \mathrm{mL}\right)$ was analysed by an electronic fluoro-optical method (DCC, DeLaval, Tumba, Sweden). Fat corrected milk yield (FCM) was calculated according to Gravert equation [33]: $\operatorname{FCM}(3.5 \%)=0.433 \times$ milk yield $(\mathrm{kg} /$ day $)+16.218 \times$ fat milk yield (kg/day). Milk fatty acids were extracted by the Folch procedure, with some variations collected in Romeu-Nadal et al. [34] and were methylated following the Nudda et al. [35] method. The equipment, column, and FAME mix used for the identification of peaks of milk fatty acid profile were the same as for the diets. Atherogenicity index (AI) and thrombogenicity index (TI) were calculated according to Ulbricht and Southgate [36]. These indices provide important information because AI is related with the ability of lipids' adhesion to immunological and circulatory system cells and TI indicates the tendency to form clots in blood vessels [8]. Desaturase indices (DI) for C14:0, C16:0, and C18:0 were calculated according to Lock and Garnsworthy [37].

In order to assess the effect of the diets on goats' metabolism, blood samples were analysed. The same day as the milk sampling was performed, the fasting animals were bled and samples were collected for glucose, urea, and $\beta$-hydroxybutyrate (BHB) analysis. Blood samples were analysed with a glucose oxidase/peroxidase kit (Ref. 11503, Biosystems, Barcelona, Spain) for glucose (mg/dL), with a kinetic method (GN 10125, Gernon, Sant Joan Despí, Spain) for urea (mg/dL), and for the BHB (mmol/L), the Ranbut D-3-Hydroxybutyrate kit (RB 1007, Randox, Crumlin, UK) was used.

\subsection{Calculations and Statistical Analysis}

The SCC data were transformed into $\log _{10}$ scores before statistical analysis (LSCC).

BW, milk yield and macro-composition, SCC, and plasmatic profile data were performed using SAS GLIMMIX (SAS Institute Inc., Cary, NC, USA) with repeated measures, introducing the covariate of the data obtained in the pre-experimental sampling into the model and considering DIET, SAMPLING, and interaction DIET $\times$ SAMPLING as fixed effects, according to the following equation:

$$
Y=\mu+D i+S j+D i x S j+\operatorname{cov} Y 0+A k+e,
$$

where $Y$ is the dependent variable, $\mu$ is the intercept, Di is the fixed effect of the diet $(i=C, A P 25, A P 40$, AP60, BB25, BB40, BB60), $S j$ is the fixed effect of sampling $(j=1,2,3), D i x S j$ is the interaction of diet with sampling, $\operatorname{cov} Y 0$ is the effect of the value of $Y$ in sampling $0, A k$ is the random effect of the animal, and $e$ is the residual error. The covariance model with a lower value of the Akaike criterion (lower AIC and BIC) was used for each variable.

Milk mineral and fatty acid profile data were analysed using SAS GLM (SAS Institute Inc., Cary, NC, USA), introducing the covariate of the data obtained in the pre-experimental sampling into the model and considering DIET as a fixed effect. The level of acceptance for significance was 0.05 .

\section{Results}

\subsection{Diet Effects on Body Weight and Feed Consumption}

Body weight is an indicator of the health status of the animal and optimising the inclusion of by-products involves assuring the proper health status of the goats. The treatments with the highest by-product inclusion showed a lower BW (40.2 and $38.7 \mathrm{~kg}$ in AP60 and BB60, respectively), while with the inclusion of $25 \%$ and $40 \%$, no differences were observed compared to C ( $42.9 \mathrm{~kg}$, Table 3 ). 
Sampling and interaction Treatment $\times$ Sampling also had a significant effect on BW as an increase $(p<0.001)$ was observed in sampling 2 in treatments with $40 \%$ of by-product $(+1.9$ and $+2.4 \mathrm{~kg}$ in BB40 and AP40, respectively) and then in sampling 3, they descended again. Diets were offered in a similar amount but the goats in the different treatments showed different consumptions, with group $C$ showing the highest (2.21 kg DM/day), whereas the lowest consumption was observed in groups BB40 (1.38 kg DM/day) and BB60 (1.27 kg DM/day) compared to the other treatments, which showed intermediate consumption (AP25: 1.52, AP40: 1.54, AP60: 1.57, and BB25: $1.65 \mathrm{~kg}$ DM/day).

Table 3. Body weight, milk yield, and composition and SCC, according to the effects considered.

\begin{tabular}{|c|c|c|c|c|c|c|c|c|c|c|c|}
\hline \multirow{2}{*}{ Variable } & \multicolumn{8}{|c|}{ Diets } & \multicolumn{3}{|c|}{ Significance } \\
\hline & $\mathrm{C}$ & AP25 & AP40 & AP60 & BB25 & BB40 & BB60 & SEM & Diet & Sampling & Diet $x$ Sampling \\
\hline BW (kg) & $42.9 \mathrm{a}$ & $41.6 \mathrm{ab}$ & $42.2 \mathrm{a}$ & $40.2 \mathrm{bc}$ & $41.9 \mathrm{ab}$ & $41.9 \mathrm{ab}$ & $38.7 \mathrm{c}$ & 0.69 & $* * *$ & $* * *$ & $* * *$ \\
\hline Milk yield (kg/day) & $2.24 \mathrm{a}$ & $2.15 \mathrm{ab}$ & $2.14 a b c$ & $1.92 \mathrm{bcd}$ & 1.90 cde & $1.76 \mathrm{de}$ & $1.66 \mathrm{e}$ & 0.090 & $* * *$ & $* *$ & $* * *$ \\
\hline $\operatorname{FCM}(3.5 \% ; \mathrm{kg} /$ day $)$ & $2.31 \mathrm{ab}$ & $2.42 \mathrm{a}$ & $2.26 \mathrm{ab}$ & $2.17 \mathrm{abc}$ & $2.03 \mathrm{bc}$ & $2.00 \mathrm{bc}$ & $1.88 \mathrm{c}$ & 0.120 & $* *$ & $* *$ & $*$ \\
\hline Fat $(\%)$ & $3.76 \mathrm{~b}$ & $4.25 \mathrm{ab}$ & $4.06 \mathrm{ab}$ & $4.29 \mathrm{ab}$ & $4.02 \mathrm{ab}$ & $4.25 \mathrm{ab}$ & $4.58 \mathrm{a}$ & 0.218 & $* *$ & n.s. & * \\
\hline Protein $(\%)$ & 3.39 & 3.42 & 3.52 & 3.39 & 3.34 & 3.34 & 3.42 & 0.088 & n.s. & n.s. & n.s. \\
\hline Casein $(\%)$ & 2.68 & 2.69 & 2.76 & 2.66 & 2.65 & 2.65 & 2.72 & 0.061 & n.s. & $* * *$ & n.s. \\
\hline Whey protein $(\%)$ & 0.470 & 0.484 & 0.507 & 0.491 & 0.456 & 0.465 & 0.474 & 0.024 & n.s. & $* * *$ & $* *$ \\
\hline Lactose (\%) & 4.25 & 4.16 & 4.20 & 4.16 & 4.23 & 4.20 & 4.18 & 0.045 & n.s. & $* * *$ & $* *$ \\
\hline TS $(\%)$ & $12.0 \mathrm{~b}$ & $12.5 \mathrm{ab}$ & $12.4 \mathrm{ab}$ & $12.4 \mathrm{ab}$ & $12.2 \mathrm{ab}$ & $12.4 \mathrm{ab}$ & $12.9 \mathrm{a}$ & 0.28 & $*$ & * & * \\
\hline NFTS (\%) & 8.75 & 8.67 & 8.81 & 8.63 & 8.70 & 8.67 & 8.75 & 0.084 & n.s. & $* * *$ & n.s. \\
\hline Ash (\%) & 0.639 & 0.615 & 0.648 & 0.625 & 0.638 & 0.627 & 0.652 & 0.024 & n.s. & n.s. & * \\
\hline Milk urea $(\mathrm{mg} / \mathrm{L})$ & $617 \mathrm{ab}$ & $587 \mathrm{abc}$ & $591 \mathrm{abc}$ & $641 \mathrm{a}$ & $558 \mathrm{bc}$ & $588 \mathrm{abc}$ & $542 \mathrm{c}$ & 23.0 & $* *$ & n.s. & n.s. \\
\hline
\end{tabular}

C: Control diet; AP: Diet that includes artichoke plant silage; BB: Diet that includes broccoli by-product silage; 25, 40, and 60 inclusion level of by-product silage on dry matter basis \%; SEM: Standard error mean; BW: Body weight; LSCC: $\log _{10}$ somatic cell count; FCM: Fat corrected milk (3.5\%); UDM: Useful dry matter content (fat + protein); TS: Total solids; NFTS: Non-fat total solids; abc: Least square means within a column having different superscripts differ significantly. ${ }^{*} p<0.05$; ${ }^{* *} p<0.01$; ${ }^{* * *} p<0.001$.

\subsection{Milk Yield, Macro-Composition, and SCC}

A decrease in milk yield was observed as the percentage of inclusion of by-products increased (Table 3). C, AP25, and AP40 were the treatments with the highest milk daily yield $(2.24,2.15$, and $2.14 \mathrm{~kg} /$ day, respectively; $p<0.001)$; BB60 was associated with the lowest yield (1.66 kg/day). A tendency to decrease FCM was also observed as the percentage of inclusion of the by-product in the diet increased. The highest yield was obtained in AP25, even without significant differences compared to $\mathrm{C}$ or other AP treatments; BB25 and BB40 did not show significant differences compared to C, AP40, and AP60, whereas BB60 showed the lowest value. The interaction among sampling and treatments was significant as the milk yield and FCM were only significantly reduced in AP25 and AP60 during the experiment, but remained stable in the rest of the treatments.

The diet had no significant effect on LSCC. An increase of +0.28 Log cells $/ \mathrm{mL}(p<0.01)$ was observed in AP25 between samplings 2 and 3, so that sampling and interaction with treatment were significant.

As for the macro-composition of the milk shown in Table 3, the diet only had significant effects on fat (but also affected UDM and TS) and urea (Table 3). BB60 was the one with the highest fat value and $\mathrm{T}$ was the lowest. The significant interaction of the treatment with the sampling in fat, UDM, TS, whey protein, and lactose was due to specific increases or decreases in sampling 2 in AP40, which returned to similar values to the previous ones at sampling 3 . Both the casein content of milk and NFTS were reduced in all treatments during the experiment $(p<0.001)$. The ash content increased 0.134 percentage units in AP25 at the end of the experiment, remaining stable in the rest of the treatments. Regarding the milk urea content, AP60 was the treatment that presented the highest level $(641 \mathrm{mg} / \mathrm{dL}$; $p<0.01)$ and BB60 the lowest $(542 \mathrm{mg} / \mathrm{dL})$. 


\subsection{Milk Mineral Content}

Milk mineral profile is shown in Table 4. Only significant differences in the Mn concentration due to dietary treatment were observed, although of small magnitude. AP40 was the treatment that presented the highest level of Mn $(0.233 \mathrm{mg} / \mathrm{kg}$ DM; $p<0.05)$, followed by BB25 $(0.222 \mathrm{mg} / \mathrm{kg}$ $\mathrm{DM})$, whereas BB40 was the treatment showing the lowest value $(0.185 \mathrm{mg} / \mathrm{kg} \mathrm{DM})$. These differences between treatments are not considered biologically relevant because the greatest of them, which was between AP40 and BB40, was only $0.048 \mathrm{mg} / \mathrm{kg} \mathrm{DM}$.

Table 4. Milk mineral profile according to the effects considered.

\begin{tabular}{|c|c|c|c|c|c|c|c|c|c|}
\hline Mineral & \multicolumn{9}{|c|}{ Diets } \\
\hline $\mathrm{Na}(\mathrm{g} / \mathrm{kg} \mathrm{DM})$ & 2.59 & 2.40 & 2.23 & 2.36 & 2.53 & 2.41 & 2.68 & 0.113 & n.s. \\
\hline Mg (g/kg DM) & 0.888 & 0.837 & 0.835 & 0.932 & 0.884 & 0.813 & 0.853 & 0.047 & n.s. \\
\hline $\mathrm{K}(\mathrm{g} / \mathrm{kg} \mathrm{DM})$ & 12.0 & 11.5 & 11.2 & 11.8 & 12.1 & 10.9 & 11.5 & 0.51 & n.s. \\
\hline $\mathrm{Ca}(\mathrm{g} / \mathrm{kg}$ DM) & 8.85 & 7.56 & 8.64 & 8.81 & 8.07 & 7.85 & 7.81 & 0.495 & n.s. \\
\hline Se $(\mathrm{mg} / \mathrm{kg} \mathrm{DM})$ & 0.102 & 0.095 & 0.127 & 0.117 & 0.091 & 0.105 & 0.093 & 0.010 & n.s. \\
\hline $\mathrm{Zn}(\mathrm{mg} / \mathrm{kg} \mathrm{DM})$ & 18.6 & 21.3 & 17.1 & 28.3 & 25.9 & 20.4 & 23.5 & 2.60 & n.s. \\
\hline $\mathrm{Cu}(\mathrm{mg} / \mathrm{kg} \mathrm{DM})$ & 0.697 & 0.538 & 1.11 & 0.397 & 0.357 & 0.382 & 0.420 & 0.367 & n.s. \\
\hline $\mathrm{Fe}(\mathrm{mg} / \mathrm{kg} \mathrm{DM})$ & 2.95 & 2.16 & 2.26 & 2.72 & 2.11 & 2.22 & 2.34 & 0.557 & n.s. \\
\hline $\mathrm{Mn}(\mathrm{mg} / \mathrm{kg} \mathrm{DM})$ & $0.203 \mathrm{~b}$ & $0.198 \mathrm{~b}$ & $0.233 \mathrm{a}$ & $0.201 \mathrm{~b}$ & $0.222 \mathrm{ab}$ & $0.185 \mathrm{~b}$ & $0.192 \mathrm{~b}$ & 0.010 & * \\
\hline
\end{tabular}

C: Control diet; AP: Diet that includes artichoke plant silage; BB: Diet that includes broccoli by-product silage; 25, 40, and 60 inclusion level of by-product silage on dry matter basis \%; SEM: Standard error mean. abc: Least square means within a column with different superscripts differ significantly. ${ }^{*} p<0.05$.

\subsection{Milk Fatty Acid Profile}

Regarding the milk fatty acid profile (Table 5), some significant variations were observed, although they were quantitatively limited. Regarding the content of vaccenic acid (C18:1t11), it was observed that this was higher $(p<0.001)$ in the AP treatments, without differences compared to C. There was a higher concentration of linoleic acid (C18:2n6) in AP60 (2.53\%; $p<0.001)$; however, it was at C where a higher level of other C18: 2 isomers was observed. An increase $(p<0.001)$ of $\alpha$-linolenic acid (C18:3n3) was observed as the level of AP inclusion in the ration was higher and AP60 presented a higher level $(0.242 \%)$. AP treatments were also those with the highest content $(p<0.01)$ in rumenic acid (CLA c9, t11), although subsequently no significant differences were found in the sum of isomers of CLA (conjugated linoleic acid) between treatments, except of BB60, of which their content was the smallest of all. Table 6 shows that as the percentage of AP inclusion increased, so did the PUFA content, and AP60 was the treatment with the highest content $(p<0.001)$ compared to all the BB treatments, without differences from $\mathrm{C}$ or the rest of the AP treatments. AP60 presented the highest levels $(p<$ $0.001)$ of $\mathrm{n} 3(0.275 \%)$ and $\mathrm{n} 6(2.79 \%)$ fatty acids, the latter without differences compared to $C$ or the other AP treatments. It also achieved the lowest $(p<0.001)$ ratio n6/n3 obtained together with BB60 (10.3 and 12.3, respectively). Regarding the lipid quality indices related to human health (AI and TI), AP40 and AP60 were the ones with the lowest value $(p<0.001)$ and therefore, were healthier. Regarding the desaturation indices of the myristic (DI14), palmitic (DI16), and stearic (DI18) fatty acids, the differences found between treatments were of small magnitude. BB60 was the one with the highest value in DI14 and DI18 $(0.012 \%$ and $2.08 \%$, respectively; $p<0.001)$ and AP60 presented a higher value of DI16 $(0.061 \% ; p<0.01)$. 
Table 5. Fatty acid composition ( $\mathrm{g} / 100 \mathrm{~g}$ total fatty acids) measured in milk according to the effects considered.

\begin{tabular}{|c|c|c|c|c|c|c|c|c|c|}
\hline \multirow{2}{*}{ Fatty Acid } & \multicolumn{9}{|c|}{ Diets } \\
\hline & $\mathrm{C}$ & AP25 & AP40 & AP60 & BB25 & BB40 & BB60 & SEM & Significance \\
\hline C4:0 & 2.21 & 2.66 & 2.53 & 2.57 & 2.53 & 2.62 & 2.67 & 0.586 & n.s. \\
\hline C6:0 & 3.05 & 3.59 & 3.41 & 3.51 & 3.54 & 3.55 & 3.61 & 0.795 & n.s. \\
\hline C7:0 & $0.052 \mathrm{ab}$ & $0.060 \mathrm{ab}$ & $0.070 \mathrm{ab}$ & $0.046 b$ & $0.073 \mathrm{ab}$ & $0.071 \mathrm{ab}$ & $0.077 \mathrm{a}$ & 0.024 & $*$ \\
\hline C8:0 & 4.11 & 4.57 & 4.67 & 4.32 & 4.64 & 4.77 & 4.28 & 0.981 & n.s. \\
\hline C9:0 & $0.065 b$ & $0.077 \mathrm{ab}$ & $0.095 \mathrm{a}$ & $0.088 \mathrm{ab}$ & $0.102 \mathrm{a}$ & $0.102 \mathrm{a}$ & $0.102 \mathrm{a}$ & 0.023 & $*$ \\
\hline $\mathrm{C} 10: 0$ & 13.2 & 15.0 & 14.7 & 14.5 & 15.6 & 15.6 & 15.3 & 3.03 & n.s. \\
\hline C10:1 c9 & 0.037 & 0.040 & 0.033 & 0.036 & 0.047 & 0.036 & 0.034 & 0.017 & n.s. \\
\hline C11:0 & $0.197 \mathrm{ab}$ & $0.171 \mathrm{bc}$ & $0.186 \mathrm{abc}$ & $0.157 \mathrm{c}$ & $0.190 \mathrm{ab}$ & $0.201 \mathrm{a}$ & $0.193 \mathrm{ab}$ & 0.022 & $* *$ \\
\hline C12:0 & $3.23 \mathrm{a}$ & $2.81 \mathrm{bc}$ & $3.10 \mathrm{abc}$ & $2.66 \mathrm{c}$ & $3.11 \mathrm{abc}$ & $3.31 \mathrm{ab}$ & $2.93 \mathrm{abc}$ & 0.274 & $* * *$ \\
\hline C12:1 c9 & 0.032 & 0.024 & 0.035 & 0.030 & 0.039 & 0.037 & 0.024 & 0.012 & n.s. \\
\hline iso $\mathrm{C} 13: 0$ & $0.017 \mathrm{~b}$ & $0.016 \mathrm{~b}$ & $0.026 \mathrm{ab}$ & $0.028 \mathrm{a}$ & $0.027 \mathrm{a}$ & $0.016 \mathrm{~b}$ & $0.019 \mathrm{ab}$ & 0.008 & $*$ \\
\hline anteiso $\mathrm{C} 13: 0$ & 0.025 & 0.025 & 0.030 & 0.030 & 0.030 & 0.031 & 0.026 & 0.008 & n.s. \\
\hline iso C14:0 & $0.055 \mathrm{~b}$ & $0.045 \mathrm{~b}$ & $0.060 \mathrm{~b}$ & $0.067 \mathrm{ab}$ & $0.063 \mathrm{ab}$ & $0.058 \mathrm{~b}$ & $0.084 \mathrm{a}$ & 0.019 & $* *$ \\
\hline C14:0 & $7.62 \mathrm{ab}$ & $7.08 \mathrm{ab}$ & $6.92 \mathrm{ab}$ & $6.74 \mathrm{~b}$ & $7.59 \mathrm{ab}$ & $7.56 \mathrm{ab}$ & $7.76 \mathrm{a}$ & 0.568 & $*$ \\
\hline iso $\mathrm{C} 15: 0$ & $0.174 \mathrm{abcd}$ & $0.130 \mathrm{~b}$ & $0.178 \mathrm{abc}$ & $0.184 \mathrm{a}$ & $0.163 \mathrm{abcd}$ & $0.154 \mathrm{bc}$ & $0.152 \mathrm{bcd}$ & 0.021 & *** \\
\hline anteiso $\mathrm{C} 15: 0$ & $0.226 \mathrm{a}$ & $0.170 \mathrm{c}$ & $0.208 \mathrm{ab}$ & $0.223 \mathrm{a}$ & $0.189 \mathrm{bc}$ & $0.181 \mathrm{c}$ & 0.181 c & 0.021 & $* * *$ \\
\hline C14:1 c9 & $0.073 b c$ & $0.062 \mathrm{c}$ & $0.067 \mathrm{bc}$ & $0.076 \mathrm{abc}$ & $0.071 \mathrm{bc}$ & $0.080 \mathrm{ab}$ & $0.090 \mathrm{a}$ & 0.011 & $* * *$ \\
\hline C15:0 & $0.652 b c$ & $0.524 \mathrm{~d}$ & $0.617 \mathrm{c}$ & $0.753 \mathrm{ab}$ & $0.675 \mathrm{bc}$ & $0.717 \mathrm{~b}$ & $0.818 \mathrm{a}$ & 0.066 & $* * *$ \\
\hline C15:1 & $0.070 \mathrm{a}$ & $0.042 \mathrm{~d}$ & $0.048 \mathrm{~cd}$ & $0.064 \mathrm{ab}$ & $0.055 \mathrm{bc}$ & $0.061 \mathrm{ab}$ & $0.055 \mathrm{bcd}$ & 0.011 & $* * *$ \\
\hline iso $\mathrm{C} 16: 0$ & $0.176 \mathrm{c}$ & $0.147 \mathrm{~d}$ & $0.188 \mathrm{bc}$ & $0.225 \mathrm{a}$ & $0.178 \mathrm{c}$ & $0.204 \mathrm{ab}$ & $0.218 \mathrm{a}$ & 0.022 & $* * *$ \\
\hline C16:0 & $21.5 \mathrm{ab}$ & $22.3 \mathrm{ab}$ & $20.4 \mathrm{ab}$ & $20.5 b$ & $22.1 \mathrm{ab}$ & $22.0 \mathrm{ab}$ & $23.9 \mathrm{a}$ & 1.67 & $* *$ \\
\hline $\mathrm{C} 16: 1 \mathrm{t} 4$ & $0.039 \mathrm{ab}$ & $0.003 \mathrm{~b}$ & $0.040 \mathrm{ab}$ & $0.070 \mathrm{a}$ & $0.003 \mathrm{~b}$ & $0.024 \mathrm{ab}$ & $0.048 \mathrm{ab}$ & 0.049 & * \\
\hline $\mathrm{C} 16: 1 \mathrm{t} 5$ & $0.023 \mathrm{ab}$ & $0.005 \mathrm{ab}$ & $0.029 \mathrm{ab}$ & $0.043 \mathrm{a}$ & $0.000 \mathrm{~b}$ & $0.007 \mathrm{ab}$ & $0.042 \mathrm{ab}$ & 0.036 & $*$ \\
\hline C16:1 t6-7 & 0.105 & 0.089 & 0.112 & 0.139 & 0.097 & 0.060 & 0.085 & 0.148 & n.s. \\
\hline C16:1 t9 & 0.193 & 0.168 & 0.187 & 0.166 & 0.188 & 0.175 & 0.137 & 0.114 & n.s. \\
\hline C16:1 t10 & 0.028 & 0.002 & 0.020 & 0.013 & 0.030 & 0.007 & 0.012 & 0.034 & n.s. \\
\hline $\mathrm{C} 16: 1 \mathrm{t} 11-12$ & 0.012 & 0.041 & 0.023 & 0.048 & 0.019 & 0.063 & 0.041 & 0.037 & n.s. \\
\hline C16:1 c7 & 0.203 & 0.182 & 0.205 & 0.204 & 0.191 & 0.178 & 0.176 & 0.043 & n.s. \\
\hline $\mathrm{C} 16: 1 \mathrm{c} 9$ & $0.436 \mathrm{c}$ & $0.449 \mathrm{bc}$ & $0.491 \mathrm{bc}$ & $0.542 \mathrm{ab}$ & $0.482 \mathrm{bc}$ & $0.475 \mathrm{bc}$ & $0.617 \mathrm{a}$ & 0.080 & $* *$ \\
\hline C16:1 c10 & $0.029 \mathrm{ab}$ & $0.000 \mathrm{~b}$ & $0.031 \mathrm{ab}$ & $0.047 \mathrm{a}$ & $0.000 \mathrm{~b}$ & $0.012 \mathrm{ab}$ & $0.033 \mathrm{ab}$ & 0.040 & * \\
\hline C16:1 c11 & 0.000 & 0.002 & 0.004 & 0.006 & 0.000 & 0.003 & 0.011 & 0.009 & n.s. \\
\hline iso $\mathrm{C} 17: 0$ & $0.249 \mathrm{ab}$ & $0.234 \mathrm{ab}$ & $0.275 \mathrm{a}$ & $0.223 \mathrm{ab}$ & $0.207 \mathrm{ab}$ & $0.184 b$ & $0.165 b$ & 0.060 & $* *$ \\
\hline anteiso $\mathrm{C} 17: 0$ & $0.287 \mathrm{a}$ & $0.218 \mathrm{bc}$ & $0.263 \mathrm{ab}$ & $0.293 \mathrm{a}$ & $0.257 \mathrm{ab}$ & $0.180 \mathrm{c}$ & $0.282 \mathrm{a}$ & 0.049 & $* * *$ \\
\hline C17:0 & $0.555 b$ & $0.485 \mathrm{~b}$ & $0.516 \mathrm{~b}$ & $0.703 \mathrm{a}$ & $0.536 \mathrm{~b}$ & $0.541 \mathrm{~b}$ & $0.636 \mathrm{a}$ & 0.058 & $* * *$ \\
\hline C17:1 c6-7 & 0.040 & 0.046 & 0.050 & 0.049 & 0.041 & 0.056 & 0.034 & 0.018 & n.s. \\
\hline C17:1 c8 & $0.000 \mathrm{~b}$ & $0.002 \mathrm{~b}$ & $0.000 \mathrm{~b}$ & $0.003 \mathrm{~b}$ & $0.002 \mathrm{~b}$ & $0.014 \mathrm{~b}$ & $0.035 \mathrm{a}$ & 0.012 & $* * *$ \\
\hline C17:1 c9 & $0.104 \mathrm{~b}$ & $0.114 \mathrm{~b}$ & $0.121 \mathrm{~b}$ & $0.195 \mathrm{a}$ & $0.119 \mathrm{~b}$ & $0.159 \mathrm{a}$ & $0.215 \mathrm{a}$ & 0.023 & $* * *$ \\
\hline isoC18:0 & $0.034 \mathrm{ab}$ & $0.041 \mathrm{ab}$ & $0.047 \mathrm{~b}$ & $0.047 \mathrm{ab}$ & $0.034 \mathrm{~b}$ & $0.057 \mathrm{a}$ & $0.053 \mathrm{ab}$ & 0.013 & $*$ \\
\hline C18:0 & $14.1 \mathrm{a}$ & $12.5 \mathrm{ab}$ & $13.2 \mathrm{ab}$ & $12.2 \mathrm{ab}$ & $12.7 \mathrm{a}$ & $11.8 \mathrm{ab}$ & $9.9 \mathrm{~b}$ & 0.85 & $* * *$ \\
\hline C18:1 t4 & $0.068 \mathrm{ab}$ & $0.085 \mathrm{a}$ & $0.067 \mathrm{ab}$ & $0.049 \mathrm{bc}$ & $0.082 \mathrm{a}$ & $0.043 c$ & $0.045 \mathrm{c}$ & 0.016 & $* * *$ \\
\hline $\mathrm{C} 18: 1 \mathrm{t} 5$ & $0.030 \mathrm{ab}$ & $0.024 \mathrm{~b}$ & $0.031 \mathrm{ab}$ & $0.033 \mathrm{ab}$ & $0.038 \mathrm{a}$ & $0.017 \mathrm{~b}$ & $0.026 \mathrm{ab}$ & 0.011 & $* *$ \\
\hline C18:1 t6-8 & $0.196 \mathrm{a}$ & $0.166 \mathrm{abc}$ & $0.180 \mathrm{ab}$ & $0.134 \mathrm{~d}$ & $0.146 \mathrm{bcd}$ & $0.171 \mathrm{abc}$ & $0.123 \mathrm{~cd}$ & 0.027 & $* *$ \\
\hline C18:1 t9 & $0.269 \mathrm{a}$ & $0.271 \mathrm{ab}$ & $0.245 \mathrm{abc}$ & $0.234 \mathrm{bcd}$ & $0.233 \mathrm{bcd}$ & $0.213 \mathrm{abcd}$ & $0.193 \mathrm{~d}$ & 0.028 & $* *$ \\
\hline C18:1 t10 & $0.276 \mathrm{a}$ & $0.235 \mathrm{ab}$ & $0.230 \mathrm{ab}$ & $0.205 \mathrm{~b}$ & $0.220 \mathrm{ab}$ & $0.235 \mathrm{ab}$ & $0.219 \mathrm{~b}$ & 0.047 & * \\
\hline $\mathrm{C} 18: 1 \mathrm{t} 11$ & $1.30 \mathrm{a}$ & $1.33 \mathrm{a}$ & $1.35 \mathrm{a}$ & $1.25 \mathrm{ab}$ & $0.98 \mathrm{bc}$ & $0.95 \mathrm{c}$ & $0.81 \mathrm{c}$ & 0.169 & $* * *$ \\
\hline C18:1 t12 & $0.492 \mathrm{a}$ & $0.471 \mathrm{a}$ & $0.460 \mathrm{abc}$ & $0.396 b$ & $0.383 \mathrm{bcd}$ & $0.377 \mathrm{bcd}$ & $0.317 \mathrm{~d}$ & 0.049 & $* * *$ \\
\hline C18:1 t13-14 & 0.059 & 0.000 & 0.058 & 0.000 & 0.062 & 0.114 & 0.037 & 0.117 & n.s. \\
\hline C18:1 c9 & $18.0 \mathrm{ab}$ & $17.6 \mathrm{ab}$ & $18.2 \mathrm{ab}$ & $19.0 \mathrm{a}$ & $16.3 \mathrm{~b}$ & $16.9 \mathrm{ab}$ & $175 \mathrm{ab}$ & 1.45 & * \\
\hline C18:1 c11 & $0.043 \mathrm{ab}$ & $0.055 \mathrm{ab}$ & $0.038 \mathrm{ab}$ & $0.005 \mathrm{~b}$ & $0.045 \mathrm{ab}$ & $0.155 \mathrm{a}$ & $0.052 \mathrm{ab}$ & 0.121 & $*$ \\
\hline C18:1 c12 & 0.587 a & $0.565 \mathrm{abc}$ & $0.581 \mathrm{a}$ & $0.536 \mathrm{abc}$ & $0.511 \mathrm{bc}$ & $0.569 \mathrm{ab}$ & $0.511 \mathrm{c}$ & 0.047 & $* *$ \\
\hline C18:1 c13 & 0.124 & 0.116 & 0.112 & 0.115 & 0.115 & 0.119 & 0.112 & 0.019 & n.s. \\
\hline C18:1 c14 & $0.424 \mathrm{a}$ & $0.395 \mathrm{ab}$ & $0.375 \mathrm{ab}$ & $0.326 b$ & $0.371 \mathrm{~b}$ & $0.365 b$ & $0.329 \mathrm{~b}$ & 0.040 & $* *$ \\
\hline C18:1 c15 & 0.206 & 0.192 & 0.195 & 0.213 & 0.198 & 0.208 & 0.209 & 0.028 & n.s. \\
\hline $\mathrm{C} 18: 2$ c9,t13 & $0.294 \mathrm{a}$ & $0.229 \mathrm{abc}$ & $0.246 \mathrm{ab}$ & $0.188 \mathrm{c}$ & $0.220 \mathrm{bc}$ & $0.220 \mathrm{abc}$ & $0.174 \mathrm{abc}$ & 0.044 & $* *$ \\
\hline $\mathrm{C} 18: 2$ t8,c13 & $0.098 \mathrm{a}$ & $0.084 \mathrm{ab}$ & $0.083 \mathrm{ab}$ & $0.089 \mathrm{ab}$ & $0.074 \mathrm{~b}$ & $0.089 \mathrm{ab}$ & $0.092 \mathrm{ab}$ & 0.019 & * \\
\hline C18:2 t9,12 & 0.000 & 0.000 & 0.007 & 0.057 & 0.000 & 0.000 & 0.008 & 0.034 & n.s. \\
\hline $\mathrm{C} 18: 2$ c9,t12 & $0.154 \mathrm{a}$ & $0.117 \mathrm{ab}$ & $0.112 \mathrm{~b}$ & $0.104 \mathrm{~b}$ & $0.106 \mathrm{~b}$ & $0.107 \mathrm{~b}$ & $0.101 \mathrm{~b}$ & 0.031 & $* *$ \\
\hline C18:2 t11,c15 & $0.011 \mathrm{ab}$ & $0.004 \mathrm{~b}$ & $0.014 \mathrm{a}$ & $0.017 \mathrm{a}$ & $0.013 \mathrm{ab}$ & $0.010 \mathrm{~b}$ & $0.017 \mathrm{a}$ & 0.008 & $* *$ \\
\hline C18:2n6 & $2.59 \mathrm{abcd}$ & $2.40 \mathrm{ab}$ & $2.42 \mathrm{ab}$ & $2.53 \mathrm{a}$ & $2.10 \mathrm{c}$ & $2.26 \mathrm{bc}$ & $1.98 \mathrm{bcd}$ & 0.193 & $* * *$ \\
\hline $\mathrm{C} 20: 0$ & $0.233 \mathrm{~d}$ & $0.267 \mathrm{bc}$ & $0.280 \mathrm{~b}$ & $0.350 \mathrm{a}$ & $0.237 \mathrm{~cd}$ & $0.241 \mathrm{~cd}$ & $0.225 \mathrm{~d}$ & 0.029 & $* * *$ \\
\hline C18:3n6 & 0.025 & 0.022 & 0.027 & 0.023 & 0.015 & 0.010 & 0.019 & 0.014 & n.s. \\
\hline C20:1 c9 & $0.012 \mathrm{ab}$ & $0.010 \mathrm{~b}$ & $0.017 \mathrm{ab}$ & $0.029 \mathrm{a}$ & $0.000 \mathrm{~b}$ & $0.007 \mathrm{~b}$ & $0.008 \mathrm{~b}$ & 0.015 & $* *$ \\
\hline C20:1 c11 & 0.038 & 0.050 & 0.053 & 0.049 & 0.052 & 0.053 & 0.040 & 0.018 & n.s. \\
\hline C18:3n3 & $0.183 \mathrm{~b}$ & $0.145 \mathrm{c}$ & $0.152 \mathrm{bc}$ & $0.242 \mathrm{a}$ & $0.156 \mathrm{bc}$ & $0.179 \mathrm{bc}$ & $0.173 \mathrm{bc}$ & 0.025 & $* * *$ \\
\hline CLA c9,t11 & $0.486 \mathrm{bc}$ & $0.510 \mathrm{abc}$ & $0.527 \mathrm{ab}$ & $0.538 \mathrm{ab}$ & $0.370 \mathrm{bc}$ & $0.377 \mathrm{c}$ & $0.344 \mathrm{bc}$ & 0.064 & $* *$ \\
\hline CLA t9,c11 & $0.044 \mathrm{~b}$ & $0.032 \mathrm{c}$ & $0.038 \mathrm{bc}$ & $0.058 \mathrm{a}$ & $0.030 \mathrm{c}$ & $0.032 \mathrm{c}$ & $0.035 \mathrm{bc}$ & 0.009 & $* * *$ \\
\hline CLA t10,c12 & 0.024 & 0.026 & 0.029 & 0.039 & 0.013 & 0.010 & 0.024 & 0.024 & n.s. \\
\hline CLA t12,14 & 0.017 & 0.012 & 0.023 & 0.025 & 0.009 & 0.006 & 0.022 & 0.017 & n.s. \\
\hline$\sum$ CLA & $0.528 \mathrm{a}$ & $0.550 \mathrm{a}$ & $0.549 \mathrm{a}$ & $0.532 \mathrm{a}$ & $0.529 \mathrm{a}$ & $0.531 \mathrm{a}$ & $0.482 \mathrm{~b}$ & 0.019 & $* * *$ \\
\hline C20:2n6 & 0.033 & 0.027 & 0.038 & 0.040 & 0.044 & 0.036 & 0.034 & 0.015 & n.s. \\
\hline C20:3n9 & $0.070 \mathrm{~b}$ & $0.061 \mathrm{~b}$ & $0.075 \mathrm{~b}$ & $0.116 \mathrm{a}$ & $0.080 \mathrm{~b}$ & $0.060 \mathrm{~b}$ & $0.069 \mathrm{~b}$ & 0.017 & $* * *$ \\
\hline C22:0 & 0.023 & 0.027 & 0.019 & 0.025 & 0.018 & 0.021 & 0.027 & 0.015 & n.s. \\
\hline$C 20: 3 n 3$ & $0.000 \mathrm{~b}$ & $0.004 \mathrm{~b}$ & $0.013 \mathrm{~b}$ & $0.031 \mathrm{a}$ & $0.000 \mathrm{~b}$ & $0.000 \mathrm{~b}$ & $0.000 \mathrm{~b}$ & 0.012 & $* * *$ \\
\hline C20:4n6 & $0.152 \mathrm{a}$ & $0.126 \mathrm{~b}$ & $0.151 \mathrm{a}$ & $0.165 \mathrm{a}$ & $0.158 \mathrm{a}$ & $0.146 \mathrm{ab}$ & $0.153 \mathrm{a}$ & 0.018 & $* * *$ \\
\hline C23:0 & $0.021 \mathrm{bc}$ & $0.019 \mathrm{c}$ & $0.030 \mathrm{abc}$ & $0.047 \mathrm{a}$ & $0.045 \mathrm{a}$ & $0.029 \mathrm{abc}$ & $0.038 \mathrm{ab}$ & 0.015 & $* *$ \\
\hline C20:4n3 & 0.001 & 0.001 & 0.001 & 0.001 & 0.010 & 0.001 & 0.001 & 0.009 & n.s. \\
\hline $\mathrm{C} 22: 2 \mathrm{n} 6$ & $0.000 \mathrm{c}$ & $0.026 \mathrm{~b}$ & $0.001 \mathrm{c}$ & $0.009 \mathrm{bc}$ & $0.051 \mathrm{a}$ & $0.023 b$ & $0.057 \mathrm{a}$ & 0.015 & $* * *$ \\
\hline C24:0 & 0.049 & 0.031 & 0.047 & 0.073 & 0.126 & 0.036 & 0.042 & 0.092 & n.s. \\
\hline
\end{tabular}

C: Control diet; AP: Diet that includes artichoke plant silage; BB: Diet that includes broccoli by-product silage; 25,40 , and 60 inclusion level of by-product silage on dry matter basis \%; SEM: Standard error mean; abc: Least square means within a column having different superscripts differ significantly. ${ }^{*} p<0.05 ;{ }^{* *} p<0.01$; ${ }^{* * *} p<0.001$. 
Table 6. Grouped fatty acids ( $\mathrm{g} / 100 \mathrm{~g}$ total fatty acids) and indices related to cardiovascular health and desaturation activity in milk according to the effects considered.

\begin{tabular}{|c|c|c|c|c|c|c|c|c|c|}
\hline \multirow{2}{*}{ Variable } & \multicolumn{9}{|c|}{ Diets } \\
\hline & $\mathrm{C}$ & AP25 & AP40 & AP60 & BB25 & BB40 & BB60 & SEM & Significance \\
\hline SFA & 72.2 & 73.0 & 72.2 & 70.9 & 75.1 & 74.2 & 73.6 & 2.19 & n.s. \\
\hline PUFA & $4.11 \mathrm{ab}$ & $3.86 \mathrm{abc}$ & $3.87 \mathrm{abc}$ & $4.24 \mathrm{a}$ & $3.40 \mathrm{~d}$ & $3.56 \mathrm{~cd}$ & $3.50 \mathrm{bcd}$ & 0.335 & $* * *$ \\
\hline UFA & 27.4 & 26.6 & 27.4 & 28.7 & 24.5 & 25.4 & 26.1 & 2.21 & n.s. \\
\hline SFA/UFA & 2.64 & 2.77 & 2.64 & 2.50 & 3.10 & 2.95 & 2.85 & 0.326 & n.s. \\
\hline LCFA & $39.8 \mathrm{abc}$ & $37.4 \mathrm{abc}$ & $38.7 \mathrm{abc}$ & $41.6 \mathrm{ab}$ & $36.4 \mathrm{abc}$ & $35.4 \mathrm{bc}$ & $36.0 \mathrm{c}$ & 2.88 & $* *$ \\
\hline n3 & $0.182 \mathrm{~b}$ & $0.151 \mathrm{~b}$ & $0.164 \mathrm{~b}$ & $0.275 \mathrm{a}$ & $0.157 \mathrm{~b}$ & $0.178 \mathrm{~b}$ & $0.174 \mathrm{~b}$ & 0.034 & $* * *$ \\
\hline n6 & $2.78 \mathrm{a}$ & $2.55 \mathrm{abc}$ & $2.60 \mathrm{ab}$ & $2.79 \mathrm{a}$ & $2.30 \mathrm{c}$ & $2.44 \mathrm{bc}$ & $2.18 \mathrm{bc}$ & 0.218 & $* * *$ \\
\hline n6/n3 & $15.4 \mathrm{abc}$ & $17.3 \mathrm{ab}$ & $17.4 \mathrm{a}$ & $10.3 \mathrm{~d}$ & $14.8 \mathrm{abc}$ & $13.8 \mathrm{bc}$ & $12.3 \mathrm{~cd}$ & 2.33 & $* * *$ \\
\hline AI & $2.11 \mathrm{~b}$ & $2.11 b c$ & $1.95 \mathrm{~cd}$ & $1.83 \mathrm{~d}$ & $2.37 \mathrm{a}$ & $2.28 \mathrm{ab}$ & $2.31 \mathrm{ab}$ & 0.127 & $* * *$ \\
\hline
\end{tabular}

C: Control diet; AP: Diet that includes artichoke plant silage; BB: Diet that includes broccoli by-product silage; 25 , 40, and 60 inclusion level of by-product silage on dry matter basis \%; SEM: Standard error mean; SFA: Saturated fatty acids; MUFA: Monounsaturated fatty acids; PUFA: Polyunsaturated fatty acids; UFA: Unsaturated fatty acids (MUFA + PUFA); SCFA: Short chain fatty acids (C6:0 a C10:0); MCFA: Medium chain fatty acids (C11:0 a C17:0); LCFA: Long chain fatty acids (C18:0 a C24:0); AI: Atherogenic index; TI: Thrombogenic index; DI: Desaturation index; abc: Least square means within a column having different superscripts differ significantly. ${ }^{*} p<0.05$; ${ }^{* *} p<0.01$; $* * * * 0.001$.

\subsection{Plasma Metabolic Profile}

Regarding the plasma metabolic profile (Table 7), it was observed that the greater the inclusion of BB in the diet, the higher the glucose level $(49.5$ and $50.0 \mathrm{mg} / \mathrm{dL}$ in BB40 and BB60; $p<0.001$ ), although the differences were of small magnitude ( $42.5 \mathrm{mg} / \mathrm{dL}$ in BB25). Regarding urea, $\mathrm{C}$ and AP had a higher content $(p<0.001)$, while the BB treatments obtained lower levels and BB60 showed the lowest $(33.2 \mathrm{mg} / \mathrm{dL})$. The level of BHB was higher in treatments that included less by-product, such as AP25, AP40, and BB25, while it was lower in treatments that included more BB $(0.299$ and $0.304 \mathrm{mmol} / \mathrm{L}$ in BB40 and BB60, respectively; $p<0.001$ ). There was significant interaction of treatment with sampling in the three variables due to the different behaviour throughout the experiment between treatments: Glucose increased $(p<0.001)$ with the progress of the experiment in all treatments except BB60; blood urea was reduced $(p<0.001)$ at sampling 2 in BB25 and BB40 and increased at sampling 3 in BB25, $\mathrm{BB} 40$, and BB60; BHB increased $(p<0.01)$ at the end of the experiment in BB25, BB60, and AP60, while in C, BB40, AP25, and AP40 remained stable.

Table 7. Plasmatic profile according to the effects considered.

\begin{tabular}{cccccccccccc}
\hline \multirow{2}{*}{ Variable } & \multicolumn{10}{c}{ Diets } & \multicolumn{4}{c}{ Significance } \\
\cline { 2 - 11 } & C & AP25 & AP40 & AP60 & BB25 & BB40 & BB60 & SEM & Diet & Sampling & Diet x Sampling \\
\hline Glucose $(\mathrm{mg} / \mathrm{dL})$ & $44.6 \mathrm{bc}$ & $47.7 \mathrm{ab}$ & $45.0 \mathrm{bc}$ & $48.3 \mathrm{ab}$ & $42.5 \mathrm{c}$ & $49.5 \mathrm{a}$ & $50.0 \mathrm{a}$ & 1.52 & $* * *$ & $* * *$ & $* *$ \\
Plasma urea $(\mathrm{mg} / \mathrm{dL})$ & $52.0 \mathrm{a}$ & $50.7 \mathrm{a}$ & $50.9 \mathrm{a}$ & $49.2 \mathrm{a}$ & $38.8 \mathrm{bc}$ & $39.8 \mathrm{~b}$ & $33.2 \mathrm{c}$ & 2.14 & $* * *$ & $* *$ & $* *$ \\
BHB $(\mathrm{mmol} / \mathrm{L})$ & $0.336 \mathrm{bc}$ & $0.522 \mathrm{a}$ & $0.424 \mathrm{ab}$ & $0.376 \mathrm{bc}$ & $0.421 \mathrm{ab}$ & $0.299 \mathrm{c}$ & $0.304 \mathrm{c}$ & 0.040 & $* * *$ & n.s. & $* *$ \\
\hline
\end{tabular}

C: Control diet; AP: Diet that includes artichoke plant silage; BB: Diet that includes broccoli by-product silage; 25, 40, and 60 inclusion level of by-product silage on dry matter basis \%; SEM: Standard error mean; BHB: $\beta$-hydroxybutyrate; abc: Least square means within a column having different superscripts differ significantly. ${ }^{* *} p<0.01 ;{ }^{* * *} p<0.001$.

\section{Discussion}

\subsection{Diet Effects on Body Weight and Feed Consumption}

One of the factors that affects the total volume of the diet and its consumption by livestock is the moisture content, as Jackson and Forbes [38] pointed out. This effect is especially important in the 
short term as herbivores are able to progressively modify the volume of the rumen to increase the speed of transit of the digesta [39], so in the long term, this effect would have less influence. In this experiment, carried out in the short term, diet $C$ was the one presenting the highest DM content and feed consumption (2.21 kg DM/day). On the contrary, diets BB40 and BB60 contained a greater amount of water and were bulkier and presented less consumption. In addition, diets with silage showed higher concentrations of VFA and other substances resulting from fermentation. The presence of propionic acid in BB60 (4.79 g/kg DM), as well as a higher concentration of ammonia $\mathrm{N}$ in both BB40 and BB60, also occurred in treatments with lower consumption due to the depressing effect on feed consumption demonstrated by Baumont [40]. The feed consumption of the BB treatments was superior to those found by Meneses [41] (0.508 kg DM/day) in Murciano-Granadina castrated males, whose ration incorporated $55 \%$ of BB silage. All BW values were normal for the Murciano-Granadina breed $[42,43]$. The greatest reduction in BW was in BB60, as well as the greatest reduction in feed consumption $(1.27 \mathrm{~kg} \mathrm{DM} /$ day and $38.7 \mathrm{~kg})$.

\subsection{Milk Yield, Macro-Composition, and SCC}

The treatments that presented a higher feed consumption were those that had a higher milk yield. The values obtained are similar to the yield obtained with the equation proposed by León et al. Ref. [44] for the modelling of the Murciano-Granadina lactation curve, which stands at $1.93 \mathrm{~kg} /$ day between the fourth and fifth lactation months, which is where the animals used in this experiment were located. The highest percentage of fat in BB60 (4.59\%) was probably due to a concentration effect (being the treatment with the lowest yield) and its highest content in acetic acid $(37.8 \mathrm{~g} / \mathrm{kg} \mathrm{DM}$, triple the rest) in the diet, which is an extra-lipogenic nutrient precursor of fat synthesis. Van Knegsel et al. [45] observed similar effects in dairy cows when part of the corn in the diet was replaced by beet pulp. Due to a higher fat concentration in BB60, UDM and TS also reached the highest values in this treatment $(8.03 \%$ and $12.9 \%$, respectively), exceeding $C$ by almost a percentage point. The urea level of all treatments was found to be within the optimal range for goats recommended by the Interprofessional Dairy Laboratory of Castilla-La Mancha (LILCAM), which is between 500 and $700 \mathrm{mg} / \mathrm{L}$. The differences found in the milk urea content can be explained by the different levels of feed consumption of the treatments. BB60 presented less feed consumption, in particular refusing part of the offered BB, which probably induced lower total protein intake and lower levels of milk urea, as Jimeno et al. [46] noticed.

\subsection{Milk Mineral Content}

The macromineral values correspond to those found by Mellado and García [47] in goat crossings. The composition of the diet of animals largely determines the concentrations of minerals in milk [48]. As there were no large differences in the content of the different minerals in the diets, no significant differences were subsequently observed in the milk of the different treatments, which is important for the technological aptitude of the milk, given the relevance of $\mathrm{Ca}$ and $\mathrm{P}$ in the setting and development of the microstructure of cheese [49], the main destination of goat's milk. Only the Mn had a higher concentration in AP40 $(0.233 \mathrm{mg} / \mathrm{kg} \mathrm{DM})$, although with such tight differences that they are not biologically relevant.

\subsection{Milk Fatty Acid Profile}

The milk of animals fed with AP60 had a higher content of n3 fatty acids, which caused a lower $\mathrm{n} 6 / \mathrm{n} 3$ ratio, which is positive for the prevention of coronary and cardiovascular diseases [50]. On the other hand, C, AP25, AP40, and AP60, of which their diets had the highest levels of PUFA, were the treatments with milk richest in vaccenic, rumenic, and PUFA, as reported by Collomb et al. [51], who observed differences in the PUFA and vaccenic content in the milk of cows fed with high mountain pastures and in lowland plains because the plants that made up the mountain meadows had a higher concentration of PUFA. 
Another factor that could influence the increase of PUFA in AP treatments was the slightly higher content of total polyphenols (TP) in the diet, although lower than that of BB60. However, the lower feed consumption of BB60 could mean that the total TP intake does not reach those of the AP treatments. Several studies have demonstrated the inhibitory action of dietary polyphenols on ruminal biohydrogenation of PUFA, without detrimental effects on milk yield and composition, due to interference with microbial flora [52-55]. These effects have also been observed in sheep with small amounts in the diet of by-products rich in TP [56,57]. Cappucci et al. Ref. [9] also observed how after increasing the TP content of the diet of Comisana sheep by including different levels of olive by-product, the concentration of linoleic ( $\mathrm{C} 18: 2 \mathrm{n} 6)$ and $\alpha$-linolenic $(\mathrm{C} 18: 3 \mathrm{n} 3)$ in milk was increased.

As a result of a lower milk content of C12:0, C14:0, C16:0, and C18:0, AP40 and AP60 had the lowest levels of AI and TI, so the milk of these animals would be of higher quality in terms of human health [42]. The values obtained from AI in all the treatments of this study are below those found by Molina-Alcaide et al. Ref. [42] in Murciano goats fed with conventional ration supplemented with feed blocks of olive by-products. The desaturation indices obtained in this experiment are similar to those provided by Baldin et al. Ref. [58] in a study in goats that received a dietary CLA supplement.

\subsection{Plasma Metabolic Profile}

Despite the differences found in the metabolic profile of the different treatments, glucose, urea, and BHB levels remained within the ranges considered optimal for goats [59], except for the urea value in BB60, which was slightly lower. As Friggens et al. [60] observed in goats' performance, the level of BHB was generally low and particularly in those treatments showing lower feed consumption (BB40 and BB60) because goats, as lactating animals, adapt their milk yield to the level of feed intake, as seen in Table 3. This reduces the metabolic load and allows them to maintain adequate body reserves turnover. Due to the strong relationship between plasma and milk urea content [61], the lower levels of blood urea were found in the same treatments with the lowest values of milk urea.

\section{Conclusions}

The findings of this study highlighted that a threshold level of AP or BB inclusion in dairy goat diets, without negative effects on milk yield, composition, mineral and fatty acid profile, as well as metabolic status of the animals, would be $40 \%$ of the dietary dry matter.

The inclusion of artichoke plant and broccoli by-product silages in high doses $(60 \%)$ caused lower feed consumption and lower milk yield. Inclusion at $60 \%$ of AP and BB increased the milk TS, although not enough to compensate for the reduced yield, resulting in lower FCM in the case of BB60. No differences were found regarding the milk mineral profile. Inclusion of the artichoke plant silage in the animals' diet improved the milk lipid profile from the point of view of human health (AI, TI) compared to broccoli silage, due to a lower SFA content (C12:0, C14:0, and C16:0) and a higher concentration of PUFA, especially vaccenic acid (C18:1 trans11) and rumenic acid (CLA cis9, trans11), without any differences compared to the control treatment. Regarding sanitary status, the plasma metabolic profile in broccoli treatments reflects that goats ate grains and alfalfa, whereas broccoli was the last ingredient, impairing its consumption, especially at the high concentration $(60 \%)$. In addition, the diets that included $60 \%$ of by-product silages caused a reduction in BW.

Author Contributions: Conceptualisation, G.R. and J.R.D.; Data curation, G.R., A.J.A.-B., and J.R.D.; Methodology, P.M., G.R., A.R., E.S., and J.R.D.; Resources, G.R.; Writing—original draft, P.M.; Writing—review \& editing, G.R., A.S.A., C.A.S.-C., E.S., and J.R.D. All authors have read and agreed to the published version of the manuscript.

Funding: This research received funding from the Spanish Ministry of Economy, Industry and Competitiveness and the European Regional Development Fund, grant number AGL2015-64518-R (MINECO/FEDER, UE). Paula Monllor was funded by an FPU grant (Reference number: FPU14/06058) from the Spanish Ministry of Education.

Acknowledgments: Aprovertia S.L., a technology-based company of Miguel Hernández University of Elche, provided the facilities for manufacturing the silages. 
Conflicts of Interest: The authors declare no conflict of interest. The funders had no role in the design of the study; in the collection, analyses, or interpretation of the data; in the writing of the manuscript, or in the decision to publish the results.

\section{References}

1. Guo, M. Goat milk. In Encyclopedia of Food Sciences and Nutrition, 2nd ed.; Caballero, B., Finglas, P., Toldra, F., Eds.; Academic Press: Cambridge, MA, USA, 2003; pp. 2944-2949.

2. Pulina, G.; Milán, M.; Lavín, M.; Theodoridis, A.; Morin, E.; Capote, J.; Thomas, D.; Francesconi, A.; Caja, G. Invited review: Current production trends, farm structures, and economics of the dairy sheep and goat sectors. J. Dairy Sci. 2018, 101, 6715-6729. [CrossRef]

3. Turck, D. Cow's milk and goat's milk. World Rev. Nutr. Diet 2013, 108, 56-62. [PubMed]

4. Chen, L.; Li, X.; Li, Z.; Deng, L. Analysis of 17 elements in cow, goat, buffalo, yak, and camel milk by inductively coupled plasma mass spectrometry (ICP-MS). RSC Adv. 2020, 10, 6736-6742. [CrossRef]

5. Djordjevic, J.; Ledina, T.; Baltic, M.Z.; Trbovic, D.; Babic, M.; Bulajic, S. Fatty acid profile of milk. IOP Conf. Ser. Earth Environ. Sci. 2019, 333, 012057. [CrossRef]

6. González-Arrojo, A.; Soldado, A.; Vicente, F.; Fernández Sánchez, M.L.; Sanz-Medel, A.; de la Roza-Delgado, B. Changes on levels of essential trace elements in selenium naturally enriched milk. J. Food Nutr. Res. 2016, 4, 303-308.

7. Halmemies-Beauchet-Filleau, A.; Shingfield, K.; Simpura, I.; Kokkonen, T.J.; Jaakkola, S.; Toivonen, V.; Vanhatalo, A. Effect of incremental amounts of camelina oil on milk fatty acid composition in lactating cows fed diets based on a mixture of grass and red clover silage and concentrates containing camelina expeller. J. Dairy Sci. 2017, 100, 305-324. [CrossRef]

8. Hilali, M.; Rischkowsky, B.; Iniguez, L.; Mayer, H.K.; Schreiner, M. Changes in the milk fatty acid profile of Awassi sheep in response to supplementation with agro-industrial by-products. Small Rumin. Res. 2018, 166, 93-100. [CrossRef]

9. Cappucci, A.; Alves, S.P.; Bessa, R.J.; Buccioni, A.; Mannelli, F.; Pauselli, M.; Viti, C.; Pastorelli, R.; Roscini, V.; Serra, A.; et al. Effect of increasing amounts of olive crude phenolic concentrate in the diet of dairy ewes on rumen liquor and milk fatty acid composition. J. Dairy Sci. 2018, 101, 4992-5005. [CrossRef]

10. Schulz, F.; Westreicher-Kristen, E.; Molkentin, J.; Knappstein, K.; Susenbeth, A. Effect of replacing maize silage with red clover silage in the diet on milk fatty acid composition in cows. J. Dairy Sci. 2018, 101, 7156-7167. [CrossRef]

11. Monllor, P.; Romero, G.; Sendra, E.; Atzori, A.S.; Diaz, J.R. Short-term effect of the inclusion of silage Artichoke by-products in diets of dairy goats on milk quality. Animals 2020, 10, 339. [CrossRef]

12. Caputo, A.R.; Morone, G.; Di Napoli, M.A.; Rufrano, D.; Sabia, E.; Paladino, F.; Sepe, L.; Claps, S. Effect of destoned olive cake on the aromatic profile of cows' milk and dairy products: Comparison of two techniques for the headspace aroma profile analysis. Ital. J. Agron. 2015, 10, 15. [CrossRef]

13. FAO. Food and Agriculture Organization of the United Nations. Available online: http://www.fao.org/ faostat/en/\#data/FO (accessed on 4 April 2019).

14. Hernández, F.; Pulgar, M.A.; Cid, J.M.; Moreno, R.; Ocio, E. Nutritive assessment of artichoke crop residues (Cynara scolymus L): Sun dried leaves and whole plant silage. Arch. Zootec 1992, 41, 257-264.

15. Wernli, C.; Thames, I. Utilization of fodder residue of artichoke (Cynara scolymus L.) as silage. I. Factors affecting its conservation. Av. Prod. Anim. 1989, 14, 79-89.

16. Ros, M.; Pascual, J.A.; Ayuso, M.; Morales, A.B.; Miralles, J.R.; Solera, C. Estrategias Sostenibles para un Manejo Integral de los Residuos y Subproductos Orgánicos de la Industria Agroalimentaria. Proyecto Life+ Agrowaste; CEBAS-CSIC, CTC y AGRUPAL: Murcia, España, 2012.

17. Wiedenhoeft, M.H.; Barton, B.A. Management and environment effects on brassica forage quality. Agron. J. 1907, 86, 227-232. [CrossRef]

18. Shinners, K.J.; Wepner, A.D.; Muck, R.E.; Weimer, P.J. Aerobic and anaerobic storage of single-pass, chopped corn stover. BioEnergy Res. 2010, 4, 61-75. [CrossRef]

19. Meneses, M.; Megías, M.D.; Madrid, J.; Martínez-Teruel, A.; Hernández, F.; Oliva, J. Evaluation of the phytosanitary, fermentative and nutritive characteristics of the silage made from crude artichoke (Cynara scolymus L.) by-product feeding for ruminants. Small Rumin. Res. 2007, 70, 292-296. [CrossRef] 
20. Monllor, P.; Muelas, R.; Roca, A.; Sendra, E.; Romero, G.; Díaz, J.R. Nutritive and fermentative evaluation of silages made from plant of artichoke and artichoke and broccoli by-product. In Proceedings of the XLII Nationas and XVIII International Congress of Spanish Society of Sheep and Goat Husbandry (SEOC), Salamanca, Spain, 20-22 September 2017; Spanish Society of Sheep and Goat Husbandry: Sevilla, Spain, 2017; pp. $139-145$.

21. Marsico, G.; Ragni, M.; Vicenti, A.; Jambrenghi, A.C.; Tateo, A.; Giannico, F.; Vonghia, G. The quality of meat from lambs and kids reared on feeds based on Artichoke (Cynara Scolymus L.) bracts. Acta Hortic. 2005, 681, 489-494. [CrossRef]

22. Jaramillo, D.; Buffa, M.; Rodríguez, M.; Pérez-Baena, I.; Guamis, B.; Trujillo, A.-J. Effect of the inclusion of artichoke silage in the ration of lactating ewes on the properties of milk and cheese characteristics during ripening. J. Dairy Sci. 2010, 93, 1412-1419. [CrossRef]

23. Salman, F.M.; El-Nomeary, Y.A.A.; Abedo, A.A.; Abd El-Rahman, H.H.; Mohamed, M.I.; Ahmed, S.M. Utilization of artichoke (Cynara scolymus) by-products in sheep feeding. Am.-Eurasian J. Agric. Environ. Sci. 2014, 14, 624-630.

24. Muelas, R.; Monllor, P.; Romero, G.; Sayas-Barberá, E.; Navarro, C.; Diaz, J.R.; Sendra, E. Milk technological properties as affected by including Artichoke by-products silages in the diet of dairy goats. Foods 2017, 6, 112. [CrossRef]

25. Fernández, C.; Sánchez-Séiquer, P.; Navarro, M.J.; Garcés, C. Modeling the voluntary dry matter intake in Murciano-Granadina dairy goats. In Sustainable Grazing, Nutritional Utilization and Quality of Sheep and Goat Products; Molina, A.E., Ben, S.H., Biala, K., Morand-Fehr, P., Eds.; CIHEAM: Zaragoza, Spain, 2005; pp. 395-399.

26. INRA. Alimentation des Bovins, Ovins et Caprins; Jarrige, R., Ed.; INRA: Paris, France, 1988; p. 471.

27. AOAC. Official Methods of Analysis, 16th ed.; Cunniff, P., Ed.; Association of Official Analytical Chemists: Washington, WA, USA, 1999.

28. Van Soest, P.J.; Robertson, J.B.; Lewis, B.A. Methods for dietary neutral detergent fibre and nonstarch polysacacharides in relation to animal nutrition. J. Dairy Sci. 1991, 74, 3583-3597. [CrossRef]

29. Kim, D.; Jeong, S.W.; Lee, C.Y. Antioxidant capacity of phenolic phytochemicals from various cultivars of plums. Food Chem. 2003, 81, 321-326. [CrossRef]

30. Liu, F.-X.; Fu, S.-F.; Bi, X.-F.; Chen, F.; Liao, X.-J.; Hu, X.-S.; Wu, J. Physico-chemical and antioxidant properties of four mango (Mangifera indica L.) cultivars in China. Food Chem. 2013, 138, 396-405. [CrossRef] [PubMed]

31. Menke, K.H.; Steingass, H. Estimation of the energetic feed value obtained from chemical analysis and in vitro gas production using rumen fluid. Anim. Res. 1988, 23, 103-116.

32. Kramer, J.K.G.; Fellner, V.; Dugan, M.E.R.; Sauer, F.D.; Mossoba, M.M.; Yurawecz, M.P. Evaluating acid and base catalysts in the methylation of milk and rumen fatty acids with special emphasis on conjugated dienes and total trans fatty acids. Lipids 1997, 32, 1219-1228. [CrossRef]

33. Gravert, H.O. Dairy Cattle Production; Elsevier Science: New York, NY, USA, 1987; p. 234.

34. Romeu-Nadal, M.; Morera-Pons, S.; Casteltratamiento, A.I.; López-Sabater, M.C. Comparison of two methods for the extraction of fat from human milk. Anal. Chim. Acta 2004, 513, 457-461. [CrossRef]

35. Nudda, A.; McGuire, M.; Battacone, G.; Pulina, G. Seasonal variation in conjugated linoleic acid and vaccenic acid in milk fat of sheep and its transfer to cheese and ricotta. J. Dairy Sci. 2005, 88, 1311-1319. [CrossRef]

36. Ulbricht, T.; Southgate, D. Coronary heart disease: Seven dietary factors. Lancet 1991, 338, 985-992. [CrossRef]

37. Lock, A.; Garnsworthy, P. Seasonal variation in milk conjugated linoleic acid and $\Delta 9$-desaturase activity in dairy cows. Livest. Prod. Sci. 2003, 79, 47-59. [CrossRef]

38. Jackson, N.; Forbes, T.J. The voluntary intake by cattle of four silages differing in dry matter content. Anim. Sci. 1970, 12, 591-599. [CrossRef]

39. Schettini, M.A.; Prigge, E.C.; Nestor, E.L. Influence of mass and volume of ruminal contents on voluntary intake and digesta passage of a forage diet in steers. J. Anim. Sci. 1999, 77, 1896-1904. [CrossRef] [PubMed]

40. Baumont, R. Palatabilité et comportement alimentaire chez le ruminant. INRA Prod. Anim. 1996, 9, 349-358.

41. Meneses, M. Evaluación Nutritiva y Fermentativa del Ensilado de dos Subproductos Agroindustriales, Brócoli (Brassica oleracea, L. var. Itálica) y Alcachofa (Cynara Scolymus, L) para su Empleo en la Alimentación Animal. Ph.D. Thesis, University of Murcia, Murcia, Spain, 2002. 
42. Molina-Alcaide, E.; Morales-García, E.; Martín-García, A.; Ben Salem, H.; Nefzaoui, A.; Sanz-Sampelayo, M.; Morales-García, Y.E. Effects of partial replacement of concentrate with feed blocks on nutrient utilization, microbial N flow, and milk yield and composition in goats. J. Dairy Sci. 2010, 93, 2076-2087. [CrossRef] [PubMed]

43. Fernández, C.; Pérez-Baena, I.; Marti, J.; Palomares, J.; Jorro-Ripoll, J.; Segarra, J. Use of orange leaves as a replacement for alfalfa in energy and nitrogen partitioning, methane emissions and milk performance of murciano-granadina goats. Anim. Feed. Sci. Technol. 2019, 247, 103-111. [CrossRef]

44. León, J.; Macciotta, N.P.; Gama, L.T.; Barba, C.; Delgado, J. Characterization of the lactation curve in Murciano-Granadina dairy goats. Small Rumin. Res. 2012, 107, 76-84. [CrossRef]

45. Van Knegsel, A.T.; Brand, H.V.D.; Dijkstra, J.; Van Straalen, W.; Heetkamp, M.; Tamminga, S.; Kemp, B. Dietary energy source in dairy cows in early lactation: Energy partitioning and milk composition. J. Dairy Sci. 2007, 90, 1467-1476. [CrossRef]

46. Jimeno, V.; Rebollar, P.G.; Castro, T. Nutrición y alimentación del caprino de leche en sistemas intensivos de explotación. In Proceedings of the Alimentación Práctica del Caprino de Leche en Sistemas Intensivos. XIX Curso de Especialización FEDNA, Madrid, Spain, 23-24 October 2003; pp. 155-178.

47. Mellado, M.; García, J. Effects of abortion and stage of lactation on chemical composition and mineral content of goat milk from mixed-breed goat on rangeland. APCBEE Procedia 2014, 8, 1-5. [CrossRef]

48. Rey-Crespo, F.; Miranda, M.; López-Alonso, M. Essential trace and toxic element concentrations in organic and conventional milk in NW Spain. Food Chem. Toxicol. 2013, 55, 513-518. [CrossRef]

49. Pastorino, A.; Hansen, C.; McMahon, D. Effect of $\mathrm{pH}$ on the chemical composition and structure-function relationships of cheddar cheese. J. Dairy Sci. 2003, 86, 2751-2760. [CrossRef]

50. Hu, F.B. Optimal diets for prevention of coronary heart disease. JAMA 2002, 288, 2569-2578. [CrossRef]

51. Collomb, M.; Bisig, W.; Bütikofer, U.; Sieber, R.; Bregy, M.; Etter, L. Fatty acid composition of mountain milk from Switzerland: Comparison of organic and integrated farming systems. Int. Dairy J. 2008, 18, 976-982. [CrossRef]

52. Castro-Carrera, T.; Toral, P.G.; Frutos, P.; McEwan, N.R.; Hervás, G.; Abecia, L.; Pinloche, E.; Girdwood, S.; Belenguer, A. Rumen bacterial community evaluated by 454 pyrosequencing and terminal restriction fragment length polymorphism analyses in dairy sheep fed marine algae. J. Dairy Sci. 2014, 97, 1661-1669. [CrossRef] [PubMed]

53. Buccioni, A.; Pauselli, M.; Viti, C.; Minieri, S.; Pallara, G.; Roscini, V.; Rapaccini, S.; Trabalza-Marinucci, M.; Lupi, P.; Conte, G.; et al. Milk fatty acid composition, rumen microbial population, and animal performances in response to diets rich in linoleic acid supplemented with chestnut or quebracho tannins in dairy ewes. J. Dairy Sci. 2015, 98, 1145-1156. [CrossRef] [PubMed]

54. Costa, M.; Alves, S.P.; Cabo, Â.; Guerreiro, O.; Stilwell, G.; Dentinho, M.T.; Bessa, R.J.B. Modulation ofin vitrorumen biohydrogenation byCistus ladanifertannins compared with other tannin sources. J. Sci. Food Agric. 2016, 97, 629-635. [CrossRef] [PubMed]

55. Correddu, F.; Fancello, F.; Chessa, L.; Atzori, A.; Pulina, G.; Nudda, A. Effects of supplementation with exhausted myrtle berries on rumen function of dairy sheep. Small Rumin. Res. 2019, 170, 51-61. [CrossRef]

56. Nudda, A.; Correddu, F.; Atzori, A.; Marzano, A.; Battacone, G.; Nicolussi, P.; Bonelli, P.; Pulina, G. Whole exhausted berries of Myrtus communis L. supplied to dairy ewes: Effects on milk production traits and blood metabolites. Small Rumin. Res. 2017, 155, 33-38. [CrossRef]

57. Nudda, A.; Buffa, G.; Atzori, A.S.; Cappai, M.G.; Caboni, P.; Fais, G.; Pulina, G. Small amounts of agro-industrial byproducts in dairy ewes diets affects milk production traits and hematological parameters. Anim. Feed. Sci. Technol. 2019, 251,76-85. [CrossRef]

58. Baldin, M.; Dresch, R.; De Souza, J.; Fernandes, D.; Gama, M.; Harvatine, K.; Oliveira, D. CLA induced milk fat depression reduced dry matter intake and improved energy balance in dairy goats. Small Rumin. Res. 2014, 116, 44-50. [CrossRef]

59. Rivas, J.; Rossini, M.; Colmenares, O.; Salvador, A.; Morantes, M.; Valerio, D. Effect of feeding on the profile metabolic goats in canary in the tropics. In Proceedings of the 4th Simposium of the Latinomerican Asociation in Animal Science, Quevedo, Ecuador, 13-15 November 2014; pp. 125-132. 
60. Friggens, N.; Duvaux-Ponter, C.; Etienne, M.; Mary-Huard, T.; Schmidely, P. Characterizing individual differences in animal responses to a nutritional challenge: Toward improved robustness measures. J. Dairy Sci. 2016, 99, 2704-2718. [CrossRef]

61. Bonanno, A.; Di Grigoli, A.; Di Trana, A.; Di Gregorio, P.; Tornambè, G.; Bellina, V.; Claps, S.; Maggio, G.; Todaro, M. Influence of fresh forage-based diets and $\alpha$ S1-casein (CSN1S1) genotype on nutrient intake and productive, metabolic, and hormonal responses in milking goats. J. Dairy Sci. 2013, 96, 2107-2117. [CrossRef]

(C) 2020 by the authors. Licensee MDPI, Basel, Switzerland. This article is an open access article distributed under the terms and conditions of the Creative Commons Attribution (CC BY) license (http://creativecommons.org/licenses/by/4.0/). 